$11-2020$

\title{
Extractivism: Socio-legal Approaches to Relations with Lands and Resources
}

Dayna Nadine Scott

Osgoode Hall Law School of York University, dscott@osgoode.yorku.ca

Source Publication:

Forthcoming chapter in Handbook of Law and Society.

Follow this and additional works at: https://digitalcommons.osgoode.yorku.ca/scholarly_works

Part of the Environmental Law Commons

\section{Repository Citation}

Scott, Dayna Nadine, "Extractivism: Socio-legal Approaches to Relations with Lands and Resources" (2020). Articles \& Book Chapters. 2811.

https://digitalcommons.osgoode.yorku.ca/scholarly_works/2811

This Article is brought to you for free and open access by the Faculty Scholarship at Osgoode Digital Commons. It has been accepted for inclusion in Articles \& Book Chapters by an authorized administrator of Osgoode Digital Commons. 


\section{EXTRACTIVISM: Socio-legal Approaches to Relations with Lands and Resources}

\section{Dayna Nadine Scott}

Resource extraction is an activity that humans can undertake in relation to land, resources, or elements of the earth. Mining, forestry, drilling for oil, and fracking all entail extraction. On its face, it describes the act of taking, from nature, resources for human use, typically nonrenewable resources. But 'extractivism' connotes not an activity, but a relation: here, the concept does not turn on the type of resource taken, but on the underlying political economy. That is, extractivism is a particular way of relating to nature. The term is not reserved for fossil fuels and mineral extraction; neither would it apply to the extraction of those materials in all contexts and circumstances.

Extractivism is a mode of accumulation in which a high pace and scale of 'taking' generates benefits for distant capital without generating benefits for local people. It is a way of relating to lands and waters that is non-reciprocal and oriented to the short-term. Extractivism refers to a particular logic endemic to and intensifying under contemporary global capitalism, but also with a very long history. It is a system that was installed and entrenched as early as the $16^{\text {th }}$ century, by many accounts, as colonialists chased timber, rubber, furs, petroleum and other bounty, and rendered them into global commodities.

Extractivism has been theorized in critical development studies, with leading contributions from Roger Merino Acuña and Eduardo Gudynas, as a specific type of developmental path in which the social and environmental costs of resource extraction exceed its benefits. Further, the benefits tend to be highly concentrated, while the costs are diffuse and disproportionately borne by poor and marginalized local residents. The meagre benefits that are generated (or promised) locally, such as employment, tend to be inequitably distributed, with gender being a crucial determinant. Jobs and training opportunities associated with extraction typically benefit men in the communities, while major extractive projects, through the introduction of work camps (or "man camps") and the opening up of remote areas with new infrastructure, often secured by private security services, pose profound risks to local women and girls. 
Although its adverse effects may be atmospheric (as is the case for the extraction and burning of fossil fuels) , or may be dispersed across landscapes through polluted waterways (as is the case in mining and fracking) or by associated infrastructures such as pipelines (as is the case for oil and gas), the dynamics of extraction are shaped by the reality that the 'taking' by necessity must happen in the specific places where the resources are found. Where the resources are found is in the 'extractive zone', as Macarena Gómez-Barris terms it: resource-rich regions of high biodiversity targeted by colonial paradigms, and where complex social ecologies and lifeways are dismantled to achieve conversion of environmental elements into 'resources' for capital. In the process, affected communities are often dispossessed from their means of social reproduction, land-base, social and ecological wealth and economies, and evaluated through extractive logics, for their capacity to provide wage labour for the extractive industry.

But extractivism meets fierce resistance from local communities worldwide, especially Indigenous peoples. Often this resistance exposes deep rifts between land-based peoples' cosmologies that rest on principles of deep relationality with lands, waters, and other beings, and extractive logics, in which elements of the earth are understood as resources presumed to exist for the sole purpose of providing sustenance to humans. The idea that humans may be in relationships with these elements, that these elements exist in relation to each other, and that those relations may include not just the right to 'take' but obligations to protect or to steward, is emerging as a direct challenge to extractivism. In fact, this challenge is now most forcefully expressed as one of a 'conflict of laws': with Indigenous peoples pointing to their own preexisting, still operating, and always evolving legal orders as the source of their obligations to protect and defend the land.

Across the extractive zone, struggles over territory, jurisdiction and authority are transpiring as state law, international laws and norms, and new transnational governance mechanisms are coming up against local Indigenous or customary laws and practices, forging dynamic conditions of legal pluralism. Extraction is regulated on the global, transnational, and international levels by a dizzying array of overlapping and potentially conflicting norms and processes. These include measures in public international law, such as international trade and investment law, environmental law treaties such as those governing pollution and wastes, and the Paris Climate 
Agreement, and transnational governance tools led by non-state actors such as the Equator Principles (for socially and environmental responsible lending) or the Kimberley Process (for ethical diamonds). At the same time, there are international legal norms governing the use of 'resources' that do not adopt the aims of stewardship or protection of global commons, such as atmosphere or oceans, but rather the aim of enabling efficient exploitation and protection of states' 'permanent sovereignty over natural resources'.

In direct tension with states' claims to exclusive authority, of course, are the claims of Indigenous peoples also articulated in international law norms such as the United Nations Declaration on the Rights of Indigenous Peoples (the "Declaration"). In struggles over extraction, the crucial contestation has centered on the right of Indigenous peoples to "free, prior, and informed consent" ("FPIC") in respect of developments in their territories. The claim of FPIC attempts to intervene on the governance of extraction at the global scale and is having widespread impact. The most highly contested questions, then, for socio-legal studies have become: What constitutes "consent" to extraction in the contemporary moment? How can we be confident that it is freely given? How much room for alternatives to the extraction, or for different conceptions of 'development', have to be on the table for people to be understood as actually 'choosing' an extractive project?

One marker often put forward as evidence of consent to extraction is a signed contract, or "access and benefits agreement". In fact, the dynamics of resource extraction across the globe are increasingly shaped by the negotiation of a complex web of contractual agreements. These include ostensibly 'private' contracts negotiated between extractive companies and local communities, now often called Impact-Benefit Agreements, Community-Benefit Agreements, or Mutual Benefit Agreements. They also include resource-revenue sharing agreements between regional organizations or tribal councils and various state or sub-state authorities; early exploration agreements and MOUs between Indigenous communities and mining companies; framework agreements between communities and various governments and agencies over infrastructure or environmental assessment funding, among others. Over the past several years, companies in the extractive sector have come to accept that this 'deal-making' with local 
communities is a necessary part of the game - sometimes described as getting 'social license' to extract.

But across the extractive zone, many approved or state-authorized projects are not being built because of land defence actions by local peoples, or lengthy court challenges. Often, corporations' success in the courts cannot even guarantee that projects will proceed, because of the increasing capacity of Indigenous land defenders to disrupt extractive operations by making compelling claims of competing jurisdiction, or advancing arguments based on FPIC. In these contexts, the framework provided by state law is typically not capable of achieving the 'resource certainty' that industry demands. It is here that we can observe the distinct alignment of state and industry aims that characterizes the extractivist orientation. In these conditions, negotiating a deal becomes the first priority of companies interested in advancing a controversial extractive project, and the task of facilitating those deals falls to state actors invested in re-legitimizing those projects in order to safeguard 'investment'.

This regime of contractual negotiation, or 'consent by contract', is a mode of governance that attempts to define the social, political, ecological and economic relations regarding the use of lands solely through confidential bargaining and agreement-making between private extraction companies and affected communities, but in fact affords the state a key role in setting the terms. Since their emergence in the 1990s, despite being formally 'voluntary', the negotiation of an impact-benefit agreement has become in practice almost compulsory. The basic deal is as follows: the affected community typically receives promises that the company will minimize or monitor environmental impacts, provide various economic benefits such as annual payments, and meet local employment targets. In exchange, the community promises to provide access to its lands, and offer varying degrees of support for, or acquiescence to, the project.

Many scholars have raised concerns about the way the deals are struck. These include complex questions of representation with respect to who has the authority to provide consent on behalf of a community. Confronting these questions means acknowledging the potential applicability of a plurality of applicable legal orders, including Indigenous legal orders, generating challenging questions about where authority lies, over which lands, and how community 
deliberation shapes its exercise. There are concerns about confidentiality clauses, which typically prohibit the communication of the terms of the agreement to anyone outside the negotiating process. There are also legitimate worries about the support and cooperation covenants, or what critics call "no-protest clauses", that seek to prohibit community beneficiaries from taking any actions that could undermine the company's social license.

Thus, the general thrust of critical socio-legal scholarship on the contractual regime of today's extractivism is that it tends to undermine the practical ability of Indigenous peoples to envision priorities for their lands for themselves and determines for them a set path towards extractive capitalism and a wage economy. But it is also true that the opportunity to negotiate a deal represents a chance for a community to have some influence over the form, scale, and pace of development - an outcome that is hard to otherwise come by through state public law frameworks. Thus, as political ecologists have demonstrated, even new forms of 'progressive extractivism' that incorporate benefit sharing with affected communities - a function of the contractual turn -- tend towards standard forms of economic development and a wage economy. This is because they depend on growth, an ongoing and linear process of material 'progress' that forces communities to accept a re-definition of relations with land into capitalist terms of revenues, assets and individual gain, and make affected communities more dependent on revenues generated through extractivism in order to meet their basic fiscal needs.

The fundamental problem is that the Indigenous communities whose lands are threatened by extractive projects are most often not recognized as holding the jurisdiction to decide whether permits should be granted in the first place. Notwithstanding the widespread adoption of the UN Declaration, the idea of FPIC - and conversely, the possibility that 'no' could mean 'no' - is not yet a feature of the public law regime in most jurisdictions. Thus, the contracts themselves cannot be taken as evidence of 'consent' without investigating the background context for the negotiations, including the underlying power relations. And here it is clear that the backdrop set by the formal state law supports and structures the engagement process, providing valuable resources and bargaining entitlements to the parties. State law clearly allocates the legal rights and duties that come to shape the contractual order. The most crucial of these allocations 
allows the nation state the underlying title to, and jurisdiction over, all of the lands within its borders, thus securing its ability to provide access to Indigenous lands for extractive capital.

\section{Further readings:}

Gómez-Barris, Macarena, The Extractive Zone: Social Ecologies and Decolonial Perspectives (Duke University Press, 2017).

Seck, Sara L. and Penelope Simons, "Resource Extraction and the Human Rights of Women and Girls" (2019) 31(1) Canadian Journal of Women and the Law.

Scott, Dayna Nadine, "Extraction Contracting: The Struggle for Control of Indigenous Lands" (2020) 119(2) South Atlantic Quarterly 269-299.

Szablowski, David, "Operationalizing Free, Prior, and Informed Consent in the Extractive Industry Sector? Examining the Challenges of a Negotiated Model of Justice" (2010) Canadian Journal of Development Studies 30(1), 111-130. 